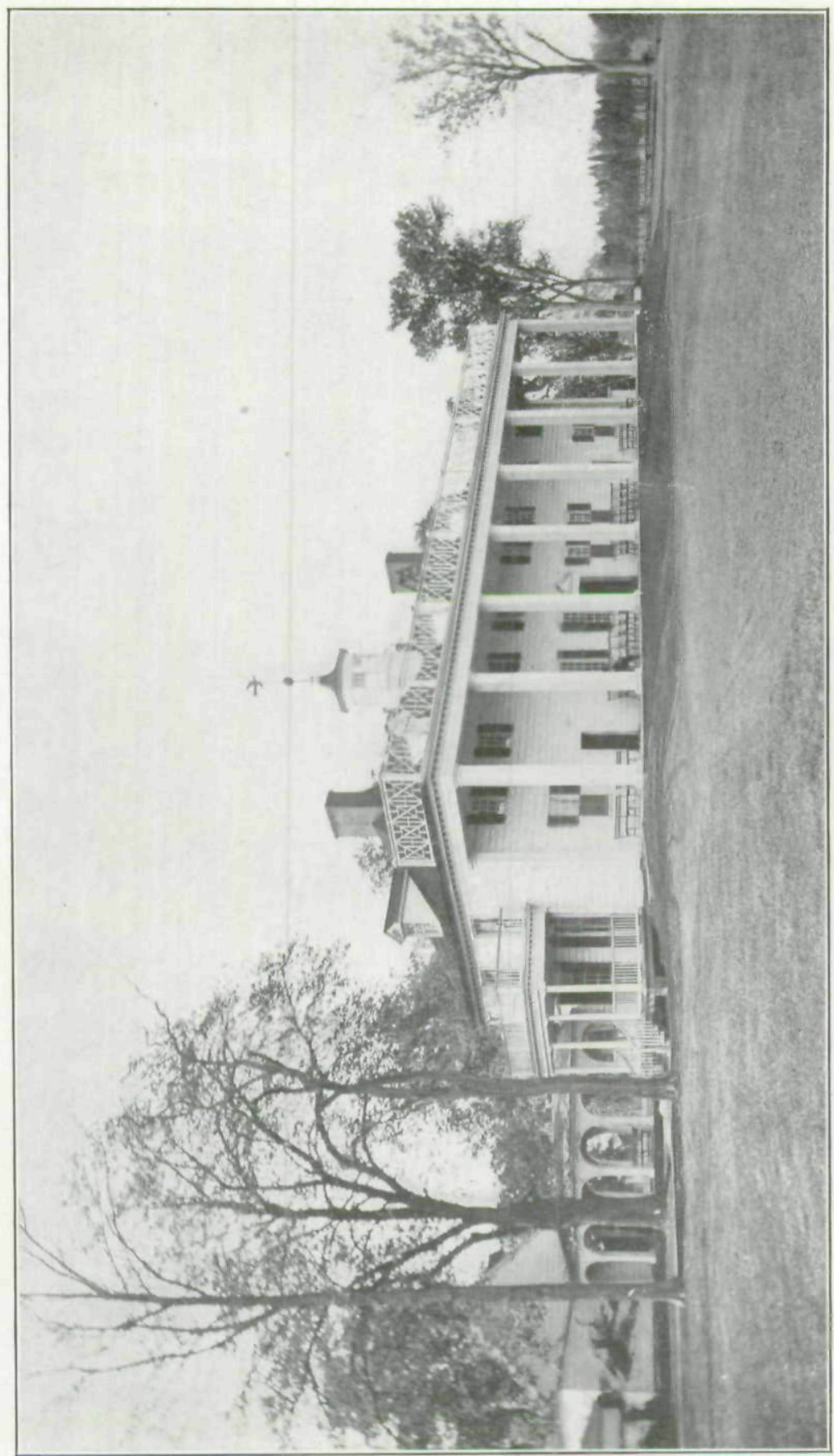

Z 


\title{
THE MOUNT VERNON LADIES ASSOCIATION OF THE UNION
}

\author{
By Mrs. Horace M. Towner ${ }^{x}$, \\ Vice-Regent for Iowa.
}

The present quickening of interest in all that pertains to the early history of the United States, and the development of the national life, is well illustrated in the renewed desire to become more familiar with all that relates to the life, character and statesmanship of the "First American," George Washington.

The honor and responsibility of restoring, preserving and caring for the home and tomb of Washington has belonged for more than half a century to an association of women known as the Mount Vernon Ladies Association of the Union, the first national organization of women in the country for patriotic purposes. To this association is due the eredit of accomplishing a task which is far reaching in its influence and importance.

At a time when Mount Vernon, with its hallowed associations as the home and last resting place of Washington, seemed in imminent danger of being lost to the people of the United States, this association of women was formed, rallied to its support patriotic eitizens throughout the country, and by the most painstaking and conscientious effort has restored and preserved this historic spot as it is seen today.

Before referring specifically to the connection which Iowa has had with Mount Vernon it may be of interest to recount briefly the events which led to the formation of the Mount Vernon Ladies Association and the purchase of the estate, which at that time consisted of two hundred acres, and included the mansion in which Washington lived and the tomb in which he is buried.

\footnotetext{
${ }^{1}$ Mrs. Towner is the wife of Hon. Horace M. Towner, of Corning, judge Third Judicial District $1890-1910$, and representative in Congress from the Eighth Iowa District since 1911. She is a member of the Iowa Library Commission.
} 
It will be remembered that Mount Vernun is part of a large tract of land in northern Virginia, lying between the Potomac and Rappahanock rivers, which was originally part of a royal grant made to Lord Culpepper. In 1674 a portion of this land came into the hands of John Washington, the great grandfather of George Washington. He devised it to his son Lawrence, who in turn left it to his son Augustine Washington, who was in 1740 in possession of 2,500 acres which included Mount Vernon. In 1743 this Augustine Washington left the estate to his son Lawrence, who built, it is thought, the original house and named the estate for Admiral Vernon of the English navy, with whom Lawrence had fought in the West Indies in 1741.

Lawrence Washington died in 1752 leaving the estate to his infant daughter, with the proviso that in the event of her death it should become the property of his younger half brother, George. The daughter died and in 1753 George Washington became the owner of Mount Vernon.

Here in 1759 he brought his bride, Martha Dandridge Custis, here he spent the important years preceding the Revolution, when not engaged in public duties; from nere he went forth to become the commander-in-chief of the American Revolutionary forces, and to Mount Vermon he returned, the vietorious general. At this time he completed the remodeling of the mansion and surroundings, giving it the form we see today.

From Mount Vernon Washington again went forth in obedience to the summons of his country to become in 1789 its first president, and to it he returned after eight years of service in establishing the Republic. Two years later he died at his beloved home on the Potomac and was buried there.

Mount Vernon was left to Washington's nephew, Bushrod Washington, the son of his brother Augustine. Judge Bushrod Washington was a member of the Supreme Court of the United States. At his death in 1829 he left the estate, now reduced to about 1,225 acres, to his nephew John A. Washington, son of his brother Corbin. John A. Washington died in 1842 leaving Mount Vernon to his wife Jane, with power to devise it as she pleased among his children. She deeded 
it in 1850 to her husband's oldest son, John Augustine Washington, who was the last private owner. Changing economic and labor conditions, the gradual impoverishment of the soil, together with the enormous demands made upon his hospitality by those whose patriotism brought them from every part of the country to visit the home and tomb of Washington, made it increasingly diffieult for John Augustine Washington to maintain the estate. He finally offered to sell it to the government of the United States, then to the commonwealth of Virginia, both of which declined to purchase it. At this juncture Miss Ann Pamela Cunningham, of South Carolina, came forward with the suggestion that the women of the country buy Mount Vernon and hold it in trust forever for the people of the United States. The movement for the purchase and restoration of Mount Vernon was started by Miss Cunningham in 1853, and from that time until the purchase was completed in 1859 she devoted her entire time and thought to the accomplishment of her purpose, overcoming obstacles which seemed at times to be almost insuperable. Miss Cunningham eonceived the idea of forming an association of women, incorporated under the laws of Virginia, consisting of a representative from each state, which should take charge of raising the money to purchase the estate, restore it to its appearance in Washington's time, and hold it as trustees for the people. The first charter was granted to the Mount Vernon Ladies Association of the Union in 1856, followed by a second charter in 1858. In this year the Association held its first meeting, Miss Cunningham presiding as regent, the representatives of the various states being known as viceregents. At this time there were twenty-two states represented by vice-regents. Iowa was one of these states. The contract to purchase Mount Vernon was signed April, 1858, and the first installment $(\$ 18,000)$ was paid on the purchase price, which had been agreed upon as $\$ 200,000$ for the two hundred acres. Rapid progress was made in raising the remainder of the money required and this is recorded in a paper published in Philadelphia known as The Mount Vernon Record. Its title page announces that it is " the organ of the Mount Vernon Ladies Association of the Union; contain- 
ing important official matter of the Association, appeals of vice-regents and lady managers, monthly reports of the secretary, lists of contributors to the fund, together with a great variety of valuable and highly interesting matter relative to our colonial and revolutionary history."

Mrs. Jane Maria Van Antwerp of Keokuk was appointed in October, 1858, as the first vice-regent for Iowa. Of Mrs. Van Antwerp The Mount Vernon Record for November of that year has the following:

"The Regent has been particularly fortunate in the selection of Mrs. Jane Maria Van Antwerp, as Vice-Regent for Iowa. Reports say-That this lady possesses every qualification which could fit her for the discharge of her duties in the honorable and important position to which she is called. She is endowed with brilliant talents; noted for her literary abilities, her energy, her practical good sense, and her patriotism.

"Mrs. Van Antwerp is the grand-daughter of Robert Yates, one of the framers of the Federal Constitution, and Chief Justice of the Supreme Court of the State of New York; daughter of Robert Van Ness Yates, Secretary of the same state; and niece of Major Fairlie, of Revolutionary memory, (who was aide-de-camp to Baron Steuben.)

"Her husband, Gen. Ver Plank Van Antwerp, has been entrusted by the government with many responsible offices. It was he who drew up the important treaty with the Sioux and Chippewa Indians, whereby an immense tract of territory, reaching nearly to Lake Superior, and embracing the fine region of the upper Mississippi, was ceded to the United States. In the same year, 1837, he assisted in the removal of the Cherokee Indians from Tennessee and Alabama, and of the Pottawattamies to the western bank of the Missouri river. His biographer, Mr. John Livingston, places him among the most eminent men of his country."

In the same issue of The Mount Vernon Record Mrs. Van Antwerp appeals to the people of Iowa as follows:

"The undersigned has recently been appointed, by the Regent of the Mount Vernon Ladies Association of the Union, Miss Anna Pamela Cunningham, of South Carolina-whose 
patriotic, zealous and untiring efforts in the cause, do her the highest honor-Vice-Regent for Iowa; and thus it becomes her duty to appeal to the people of the State, to help in this great work. It is confidently hoped that they will be no less prompt than have been those of South Carolina and New York, Virginia and Massachusetts, Alabama and Maine, in responding to the call. If, in consequence of the severe monetary pressure that still continues to prevail among us, much cannot be given by any one, let it be less, and in proportion to his, or her, ability to give; but let all give something; and the aggregate for the State may thus be made to swell to a considerable amount. The Western States are each being appealed to, in their turn, for help in this matter; and let it never be said of Iowa that she is less willing, and ready, than any of them, to do her share towards it, in proportion to her ability. Patriotism demands this at the hands of her people - and State Pride seconds to the call!

"Finally, may not the undersigned appeal, confident of a favorable response, to the Public Press of Iowa-that ever ready champion of all noble and patriotic movements-for the aid of its columns to promote and advance the one now under consideration? She truly feels she may do so, with entire reliance upon a cordial co-operation on its part, for the achievement of the object in view; for surely, there can be none other of a more patriotic and truly exalted character.

"All communications should be addressed to the undersigned at this place.

$$
\begin{aligned}
& \text { JANE MARIA VAN ANTwERP, } \\
& \text { Vice Regent for Iowa, } \\
& \text { Keokuk, November, 1858." }
\end{aligned}
$$

Mrs. Van Antwerp's appeal is followed by a list of twentyseven names of Iowans to form an "Advisory Committee of Gentlemen" headed by Governor R. P. Lowe; also a "Ladies Standing Committee" of the same number. Contributions are reported and the names of contributors given from Keokuk, Davenport, Des Moines, Iowa City, Indianola, Dubuque, Mt. Pleasant, Drakeville, Council Bluffs, Cedar Rapids, 
Bloomfield, Fairfield, Muscatine, Keosauqua, Farmington, Bonaparte and Washington. Under date of January 3, 1860, Mrs. Van Antwerp reports that Iowa has contributed over $\$ 2,100$ to the fund.

More than a quarter of the two hundred thousand dollars to be raised was contributed by Mr. Edward Everett, who, through his oration on the character of Washington, and in other ways, raised $\$ 69,064.77$.

The date of Mrs. Van Antwerp's death is uncertain but it occurred before 1872. Her suceessor as vice-regent for Iowa was Mrs. John F. Dillon of Davenport, who was appointed in 1872. Mrs. Dillon was the daughter of an Iowa pioneer, Hiram Price, who was five times elected to congress from Iowa, hetween the years 1862 and 1881 . She was the wife of Judge John F. Dillon, who served on the district bench (Clinton, Scott, Muscatine and Jackson Counties), was a member of the Iowa Supreme Court, and later became United States eircuit judge for the Eighth Federal Cireuit. Judge and Mrs. Dillon moved to New York in 1879. Mrs. Dillon was closely identified with social and civic affairs in Davenport and was the first president and long time trustee of the Davenport Library Association.

Mrs. Dillon resigned as vice-regent for Iowa late in 1873 , as she was planning an extended stay abroad with her children. In 1898, as Mrs. Dillon and her daughter were again enroute to Europe to take the cure at Nauheim, Germany, they were lost on the French steamer, La Bourgoyne, which was wreeked under tragic eircumstances.

Mrs. Dillon was deeply interested in Mount Vernon and in the effort to restore it to its appearance in Washington's time. When the mansion eame into the possession of the Association none of the original furnishings remained, the contents having been divided among the heirs of General and Mrs. Washington. It was therefore, from the beginning, the task of the members of the Association not only to restore and preserve the appearance of Mount Vernon, but to find and bring back the household belongings which Washington had in his home. This labor of love has been carried on through the years with the utmost reverence and singleness of purpose, the Association feeling itself bound by its eharter 
to keep Mount Vernon inalienably sacred to the memory of Washington. The regent and vice-regents representing the different states are appointed for life. The present regent is Miss Harriet C. Comegys of Delaware, daughter of the late Joseph P. Comegys, at one time chief justice of the Supreme Court of Delaware.

After the resignation of Mrs. Dillon Iowa was without representation in the Mount Vernon Association until the writer was appointed in 1913 . She has since then attended every meeting of the Grand Council which is held each year at Mount Vermon in May.

\section{HOW PRIMGHAR WAS NAMED.}

In the October, 1914, issue of the Annals was published an account of the origin of the name of Le Mars, Iowa, which attracted the attention of Mr. J. D. Edmundson of Des Moines, who has kindly obtained for us the appended account of the origin of the name of Primghar, Iowa :

Primghar, Iowa, January 18, 1915.

J. D. Edmundson, Des Moines, Iowa.

Dear Sir: Yours of the 15th inst. at hand in regard to the naming of Primghar.

It was named from the initials of the surnames of the eight men taking chief part in the platting; their names being as follows:

Pumphrey, J. R.

Roberts, James

Inman, C. W.

McCormick, B. F.

Green, W. C.

Hayes, D. C.

Albright, C. F.

Rerick, T. L.

It has been put in verse as follows:

"P - umphrey, the treasurer, drives the first nail;

$\mathrm{R}$-oberts, the donor, is quick on his trail;

I - nman dips slyly his first letter in;

M-cCormick adds M, which makes the full Prim.

$\mathrm{G}$-reen, thinking of groceries, gives them the G;

$\mathrm{H}$-ayes drops them an $\mathrm{H}$ without asking a fee;

A-lbright, the joker, with his jokes all at par;

$\mathrm{R}$-erick brings up the rear and crowns all, Primghar." 
Copyright of Annals of Iowa is the property of State of Iowa, by \& through the State Historical Society of Iowa and its content may not be copied or emailed to multiple sites or posted to a listserv without the copyright holder's express written permission. However, users may print, download, or email articles for individual use. 